\title{
Effect of Vaccination Against Ibr/Bvd on The Reproductive Performances of Brava Dos Açores -A Bovine Lidia Breed
}

\author{
J Pacheco-Lima ${ }^{1}$, H Silva ${ }^{1}$, JP Campillo Beneitez ${ }^{2}$, D Fernandes da Silva ${ }^{2}$ and F Moreira da Silva ${ }^{1 *}$ \\ ${ }^{1}$ Faculty of Agrarian Sciences and Environment, University of the Azores, Portugal \\ ${ }^{2}$ Hipra, Portugal
}

*Corresponding author: F Moreira da Silva, Faculty of Agrarian Sciences and Environment, University of the Azores, Animal Reproduction Angra do Heroismo, Portugal.

To Cite This Article: F Moreira da Silva, Effect of Vaccination Against Ibr/Bvd on The Reproductive Performances of Brava Dos Açores -A Bovine Lidia Breed. Am J Biomed Sci \& Res. 2019 - 6(4). AJBSR.MS.ID.001041. DOI: 10.34297/AJBSR.2019.06.001041.

Received: 眥 November 19, 2019; Published: 眥 November 26, 2019

\begin{abstract}
From February 2012 to March 2018, 94 females aged more than 24 months were randomly divided in two groups in which 43 were vaccinated and considered the experimental group and 51 were not vaccinated and used as control. For the characterization of the reproductive indexes, reproductive registers made by the animal's owners as well as data obtained through the sanitary visits and reproductive consulting of our team allow to determine the follow parameters: number of parturitions; the mean age at first calving; calving to calving interval and calving to conception interval. The first service conception rate, heat intervals as well as the percentage of cows pregnant at first pregnancy diagnosis examination was also recorded. Data obtained from all animals clearly demonstrated that all parameters studied were better in the vaccinated group when compared to unvaccinated animals. The results where the benefits were most pronounced were in the calving to calving interval, where values decreased from $889 \pm 25$ to $471 \pm 35$ days respectively to unvaccinated and vaccinated females. This great improvement led that the real fertility raised from $28.6 \%$ of the unvaccinated group to $71.1 \%$ for the vaccinated group.
\end{abstract}

Keywords: Brava dos Açores; IBR/BVD; Vaccination; Reproduction; Bullfighting bull

\section{Introduction}

Lydia cattle breed usually called "Brava" is produced extensively and therefore the clinical manifestations of any pathological process go unnoticed to those responsible for the herd. The production system in this breed is determined not only by its characteristics, but also for its productive objective [1]. The "Brava" bovine breed, due to its rusticity and peculiarity in management, develops in large land surfaces, about 500 hectares in the Alentejo and central region, 300 hectares in the Lisbon region, and 30 hectares in the Azores [2] Reproductive management is one of the main key factors in the profitability of this breed, so breeding is an essential task on farms: cows and heifers are divided into several groups, known as batting lots [3], being the calf's birth of central importance in this type of bovine production [4]. The copulation periods are from November to April/May and $90 \%$ of the delivery distribution occurs between August and March.

Productivity, in suckling cows' herds, depends on reproductive efficiency and it is often measured by the number of offspring per breeding animal per unit of time [5] and collaborators [6] postulated that keep a suckler cow for a year costs between 500 and $900 €$, being essential the production of a viable calf every 365 days, which cover this expenditure and give profits The reproductive failure is considered the main economic loss for beef cow-calf operations worldwide. The economic impact due to of embryonic and fetal losses in the US beef industry to be more than $\$ 1.2$ billion yearly, with approximately 40106 cattle exposed to breeding [7]. Several factors affect the length of the calving interval and nutrition, management and animal health are considered the most relevant [8].

The lifetime productivity of the beef-bred female commences from the onset of puberty and will be dictated by subsequent critical events including age at first calving, duration of the postpartum interval after successive calvings, conception and pregnancy rate, and ultimately manifested as length of inter-calving intervals [9]. Reproductive efficiency is key to the biological and economic 
sustainability of suckled beef enterprises as well as is a major factor determining production and ultimately the profitability of beef cow enterprises. Reproductive control of the herd is only one component of the entire farm management system. Communication to the farmer of the cost benefit of veterinary services is a key feature for the success of health of the herd [10] Reproductive efficiency is measured by the timeliness of getting a cow bred back and producing a healthy calf within a 12-month period (Table 1).
Table 1: Reproductive parameters in suckling cows (Ifende et al., 2014).

\begin{tabular}{|c|c|}
\hline Parameter & Goal \\
\hline Copulation season length & $<90$ days \\
\hline Pregnancy rate (35 days after the end of the copulation season) & $>90 \%$ \\
\hline Percentage of calves born alive & $>93 \%$ \\
\hline
\end{tabular}

How well this is done determines the number of calves that will be marketed each year, thus directly influencing upon the gross income of a cow/calf operation [10]. A long interval between deliveries results directly from the increase of the calving conception interval and is expressed by the number of "Open days". Calving and calving-to-conception intervals are commonly used as indicators of reproductive efficiency [11] Calving interval describes the number of days between successive calving's [9]. Calving intervals of 365 days would be ideal, resulting in one calving per cow per year, but intervals of 13-13.5 months are considered acceptable [11]. Optimal productivity should be the goal of each cow-calf producer and that productivity begins with cows producing at least one calf per year. This way, with proper management, including a good health and nutrition program, that goal is easily attainable [12]. This practice will result in a maximal cash flow: as the lowest calving interval, corresponds to the maximal number of calves produced [13].

Wikse [14] assumed that reproductive diseases are the greatest illness threats to the production and profitability of beef cattle herds. Infections by reproductive tract result in a wide array of losses including embryonic deaths, abortions, stillbirths and weak calves [14] These infectious can also create losses all throughout the reproductive cycle by decreasing ovulation rates, fertilization rates, embryonic, and fetal survival rates [15].

The prevalence of infectious agents in cattle herds may be due to several factors: animal and herds health management, diagnostic method, quality of the samples to be analyzed and the production system [16]. Health stress, reducing the conception rate, can be, however, restricted by a complete vaccination program, meeting mineral and nutritional requirements, and deworming young and thin cows [17]. Moreover, viral reproductive diseases, such as infectious bovine rhinotraechitis (IBR), bovine herpesvirus type 4 (BHV-4), and bovine viral diarrhea virus (BVDVV), can affect cattle all over the world, causing significant abortion losses and infertility [18] and up to $50 \%$ of pregnancy losses in cattle are associated with these infectious diseases. On the other hand, Bovine Herpesvirus Type 1 (BHV1) and bovine viral diarrhea virus (BVDVV) are two of the most important viruses of cattle, causing significant diseases. Both viruses induce a state of persistence in carrier animals, which is life-long, although the state of persistence is quite different between BHV1 and BVDVV infections [19].
Infectious bovine rhinotracheitis caused by the BHV-1, which negatively affects the production performance of infected cattle herds, results in considerable economic losses on cows [20]. BHV1 leads to the IBR respiratory disease presenting the animals genital diseases in females or males such as infectious pustular vulvovaginitis (IPV) and infectious pustular balanoposthitis (IPB). Other clinical syndromes, such as: conjunctivitis, metritis, mastitis, encephalitis, abortion, and enteritis can also be also very commonly observed [20]. The BHV-1 that causes IBR is known to directly impair ovarian function and embryo quality.

Regarding BVDV, this is the pathogen that most affects the reproductive system, in cattle, leading to poor conception rates, abortions and congenital defects, and also reducing the animal's resistance to other respiratory and enteric pathogens [21]. BVDV virus (BVDVV) infects reproductive tissues and interferes with follicular and embryo development [22,23]. Vaccinations as an integral tool for preventing disease and for maintaining herd health, may improve reproductive efficiency by reducing infertility, embryonic and fetal deaths, and abortions [24].

Up to now, there are no conclusive studies on the efficiency of vaccination against IBR/BVDV in the prevention of reproductive losses caused by these diseases in cattle. In addition, there is an evident concern that BVDV modified live vaccines may cause fetal losses, so decision-making on whether or not vaccination should be carried out is an important dilemma for practicing veterinarians working in the field [25]. Routinely, vaccination is commonly used to control of BHV1 and BVDV. For BVDV, removal of PI animals from herds and avoiding the reintroduction of PI animals into the herd (biosecurity) are also recognized as important control measures [19]. O'Connor and collaborators suggest that monitoring of IBR, and BVDV titers may be important in identifying causes of poor herd reproductive performance [26]. In view of the above exposed, and the lack of consensus on the effect of IBR/BVD vaccination on reproductive parameters in cattle, the aim of the work presented here is to study the effect of a vaccination against these two viruses on the reproductive parameters of bovine Lidia breed called "Brava dos Açores".

\section{Materials and Methods}

The present study was developed between February 2012 and March 2018 in Terceira Island using 94 females aged more 
than 24 months in a geographical area with high concentration of fighting cattle, where animals are raised using an extensive system. The color, which is not an important trait in the selection process, were usually black or grey, avoiding brindled, roan red or chestnut animals. In the same way as timid and docile animals of both sexes are culled out after special tests and sold for beef, they were excluded from the study. After selection, animals were, randomly, divided in two groups in which 43 were vaccinated and considered the experimental group and 51 were not vaccinated and used as control. Animal's belonging to the experimental group were vaccinated until 2015 with one dose, of HIPRABOVIS 4 being each time revaccinated 21-30 days later and then a booster vaccination was administrated twice a year, in the neck muscles. Heifers were vaccinated using the same protocol, in which the first vaccination was administered one month before the first mating.

Then from February 2016 to March 2018, experimental animals were vaccinated using the same protocol as afore described, with HIPRABOVIS IBR MARKER LIVE® and HIPRABOVIS BALANCE ®, to allow for IBR the identification between infected or vaccinated animals, which it could not be possible with non marker conventional IBR vaccines IBR vaccines. Data, for the characterization of the reproductive indexes was obtained using the reproductive registers made by the animal's owners as well data obtained through the sanitary visits and reproductive consulting of our team. Moreover, for each animal, all data inserted in the National Bovine Register System (SNIRB), namely parturitions and dead animals, were also considered, and the reproductive parameters were calculated according Potter and Anderson [27]. Briefly, the data were processed to determine the mean age of the breeding herd, the number of parturitions.

The average age at first calving as well as the calving to calving interval, calving to conception interval, the first service conception rate, heat intervals as well as the percent of cows pregnant at first pregnancy diagnosis. Moreover, data of the mean age of the reproductive herd was calculated including the age of all females in the right time for breeding, confirming their ovarian cyclicity by their estrous behavior or by echography made during the reproductive visits. In case of pathologic problems such as cystic ovaries, animals were treated. Concerning fertility rate, defined as the number of cows that gave birth to those placed on mating, the fertility rate considered was the annual fertility rate, many times confused with the apparent fertility rate that is often referred to by the owner. In fact, if the farm's calving interval is 450 days, for example, the cow will produce a calf every 450 days (not 365 days) and for that example the annual fertility value can be adjusting by dividing the 365 days by 450 days, which corresponds to a correction factor of 0.81 [20]. The apparent fertility rate was consequently obtained by multiplying the fertility rate by the correction factor, which has been calculated by dividing 365 by the interval between parturitions. Since the only direct contact with the animals was on the days they were vaccinated. As this is a general management situation for cattle farms in general, the protocol of work reported in this manuscript has not been previously evaluated by any ethics committee. Therefore, at no stage of the work were animal rights ignored. Statistical analysis was performed using the software SPSS and the results are presented as mean \pm standard deviation.

\section{Results and Discussion}

In the present study the effect of bovine Lidia breed called "Brava dos Açores" vaccination against IBR/BVD on the reproductive parameters, has been studied. Animals $(n=94)$ were divided in two groups in which animals belonging to group $\mathrm{A}(\mathrm{n}=$ 43) were vaccinated with HIPRABOVIS® IBR MARKER LIVE and HIPRABOVIS $®$ BALANCE and animals belonging to group B $(n=51)$ were used as control. The reproductive parameters studied was the age at the first calving, the calving to calving interval between calves, the apparent and the real fertility.

In the Table 2 can be observed the reproductive results, obtained the vaccinated and non-vaccinated with the Hiprabovis $₫$ BVD animals. When comparing the interval between calvings for the animals belonging the two groups, we noticed that this value influences the calculation of the real fertility of each group of animals (vaccinated and not vaccinated). Our research group demonstrated that, on average, the birth interval of the Bovine Lidia Called "Brava Dos Açores" was $680 \pm 75$ days, which in Spain it has been presented of $432.69 \pm 28.16$ days [28] and in Portugal mainland this interval is, on average of 535.08 \pm 196 [19]. Calving and calving-to-conception intervals are commonly used as indicators of reproductive efficiency [29]. The calving interval comprises the interval from calving to first heat (postpartum interval), number and length of services of the cow until pregnancy (conception length), and the length of gestation [30] (Table 2).

\begin{tabular}{|c|c|c|}
\hline \multicolumn{2}{|c|}{ Table 2: Reproductive results obtained for both groups, vaccinated and non-vaccinated with the HIPRABOVIS® RANGE vaccines } \\
\hline Reproductive Parameters & Vaccinated Group (43 animals) & Non-vaccinated group (51 animals) \\
\hline Mean Age & 90.07 months & 109.5 months \\
\hline Age first delivery & 40.8 months & 81.8 months \\
\hline Interval Between calvings & $471 \pm 35$ days & 68925 days \\
\hline Apparent fertility & $91.80 \%$ & $69.60 \%$ \\
\hline Real Fertility & $71.10 \%$ & $28.60 \%$ \\
\hline
\end{tabular}


When comparing the interval between calvings for the animals belonging the two groups, we noticed that this value influences the calculation of the real fertility of each group of animals (vaccinated and not vaccinated). Our research group saw that In the that the mean value of the interval between of the Bovine Lidia Called "Brava Dos Açores" births for is $680 \pm 75$ days, and in Spain it has been presented of $432.69 \pm 28.16$ days [28], and in Portugal mainland this interval is, on average of $535.08 \pm 196$ days [19] Calving and calving-to-conception intervals are commonly used as indicators of reproductive efficiency [17].The calving interval comprises the interval from calving to first heat (postpartum interval), number and length of services of the cow until pregnancy (conception length), and the length of gestation [30].

In general, but particularly for a grass-based production system with seasonal calving's, fertility is of major economic importance. A delay in conception due to poor fertility prolongs inter-calving's interval causing a shift in calving pattern, which lead to the culling of the animals [31] Different factors contribute to the variation of the calving interval. Some of them depend largely upon the genetic material and others only on the environment or the interaction between genetic and environmental factors [32] and other factors like nutritional management and BCS influence pregnancy maintenance. Moreover, diseases, such as mastitis, metritis and retained placenta may influence negatively the reproductive performance in dairy herds. Possible causes include infectious bovine rhinotracheitis (IBR), bovine virus diarrhea (BVD), leptospirosis, neosporosis, salmonellosis and venereal campylobacter can influence the fertility and increase the calving interval in herds [33].

BVDVV transmission is by nasal-pharyngeal secretions, urine, aerosols and by venereal route. Faeces are a weak source of infection. The PII calf (persistently infected immunotolerant) occurs when the fetus is infected before the 120th day of gestation; this is the time in which its immune system is mature and functional. The presence of PII animals in a group is key to the appearance of acute outbreaks of BVDV, as it is highly infective throughout its lifetime [37].

It nearly always presents slight or unapparent clinical symptoms, except in two situations: when a gestating cow is infected or when there is a co-infection with another virus, for example, those to tropism of the respiratory tract (BRSV, IBR, PI-3, Adenovirus, etc.); when cow is in heat: breeding and infertility (of 6 to 8 weeks). Early resorptions, and in pregnant cow: infection in the first four months of gestation may lead to still births, mummification and early fetal death. If the fetus becomes infected and is not aborted, it will be born a lifetime carrier of BVDV (PII). Infection after 120 days may harm the fetus (cerebral Hypoplasia) but it does not become immunotolerant. Concomitant infections: BVDV induces a marked immunosuppression that exacerbates concomitant infections and, more commonly, those that are respiratory in nature [38]. BVDV infection leads to a range of disease problems but reproductive failure is the principal cause of economic loss. Vaccination offers the advantage of controlled, safe and strategic protection against BVDV [39].

Richter and collaborators (2017) showed the ability of the virus to replicate and affect the cells of the ovarian follicles in cows at any time during follicular development in animals experimentally infected with the virus. The virus can have a detrimental impact on the developing fetus at all stages [40], but the ability of BVD to directly affect ovarian tissue is clear. Indeed, if a PI cow becomes pregnant, the result is always a PI calf, probably due to viral replication in the ovarian and reproductive tissues [41]. Therefore, Fulton postulated that it could be assumed that BVD is related to fertility problems and greater season repetition in animals that have or have had [42], detected a lower conception rate during viral circulation phases in the herd, thus confirming that BVDV infection temporarily reduced the conception rate and found clearly negative effects with more AI (artificial insemination) and pregnancy [43]. Early embryo death has been found in experimental studies about the effects of experimentally induced BVD infection in study animals [44].

The effect of fetal BVD infection depends, once again, on the type of virus, the virulence of the strain and the moment during pregnancy when the pregnant animal are infected and present viraemia [45]. It actually depends on the foetus's immune capacity to fight off the infection (Identification of cell membrane proteins linked to susceptibility to bovine viral diarrhea virus infection [50].

Infectious bovine rhinotracheitis (IBR) also known as INFECTIOUS PUSTULAR VULVOVAGINITIS, IBR, IPV, RED NOSE, has the ability of reaching the trigeminal ganglion provoking thus a latent infection. These latent infections can possibly reactivate, with or without clinical symptoms [37]. It is transmitted by direct contact and aerosol. Venereal transmission. The entire group may be affected within a period of 2 to 5 weeks. The incubation period is 3 to 7 days. Once infected, the animal will be a carrier of this herpes virus throughout its lifetime. The reproductive symptoms in the cow may include pustules reproductive symptoms in the cow may include pustules in the vaginal and vulval mucosa, clear to purulent discharge. On the other hand bulls may present pustules on the penis and prepuce, balanoposthitis (named as venereal form). Also, low reproductive indices of the farm, low fertility, endometritis and irregular returns to estrum (named as reproductive form) and miscarriages at 6 and 8 months of gestation as well as stillbirths, can be identified at herd level. Usually the reproductive form (named as the abortive form) is the most important clinical condition observed of this disease [51].

Carried in the bloodstream via white blood cells, the virus is able to gain access to the placenta and eventually the developing 
fetus. After arriving at the placental tissue, BHV-1 causes the condition placentitis, which is a general term used to describe any inflammation of the placenta. This disease is often accompanied by vasodilation (blood vessel expansion), which increases the permeability and blood flow to the placenta and thereby the developing fetus. The virus is particularly drawn to the fetus, as it prefers actively growing tissue. The time from infection to ultimate abortion varies between animals, although once the virus begins replication in the developing fetus, death can occur in as little as 24 hours [52].

Abortion may not occur immediately after death as the fetus often goes through a period of autolysis. Though embryonic death can occur early on, most loss is associated with abortions that occur in animals greater than five months in gestation. Subsequent necrosis of the fetal liver and placental tissue are often identified post-mortem. Additionally, the expelled fetus will have a dark red coloration due to the blockage of hemoglobin. The tricky part in identifying an IBR-related abortion is that often the abortion occurs without any other clinical signs of IBR. Rypula and collaborators (2017) determined that for the success in the eradication of BoHV1 , the following conditions must be fulfilled: vaccination of all animals in a timely manner constant animal movement control (article30). In fact, systematic prophylactic vaccination, live or inactivated vaccines are a way to control this disease in cow herds.

Abortion rates associated with IBR have been reported to range from 5 to 60 percent in herds without a vaccination program. [37]. Management techniques to prevent pregnancy loss in dairy herds, such as hormonal manipulation, thermal comfort, and nutritional management are increasingly being implemented into dairy systems worldwide [53]. Conversely, immunization strategies developed to reduce the impact of reproductive diseases, such as vaccination against IBR, and BVD, do not receive proper attention. The target animals and vaccination regimes for vaccines against the bovine rhinotracheitis (IBR) and the bovine viral diarrhea virus (BVDV) are very similar. The two vaccines can be applied at the same day for the first or second dose of the BVD basic vaccination and then at the booster vaccinations [54].

Vaccination is therefore widely applied to control these viruses. The target animals and vaccination regimes for BHV-1 and BVD vaccines are very similar. In general, multivalent cattle vaccines are the preferred choice of farmers and veterinarian because they simplify animal handling and therefore reduce costs of vaccination and animal stress. In general, multivalent cattle vaccines are the preferred choice of farmers and veterinarian because they simplify animal handling, reducing costs of vaccination and animal stress. (Compatibility of a live infectious bovine rhinotraheitis (IBR) markervaccine and an inactivated bovine viral diarrhea virus (BVDV) vaccine). In compliance with the BHV-1 eradication programs, it is essential that vaccines allow differentiation between vaccinated and infected animals (so-called IBR marker vaccines)
[55]. In order to respond to the market requirements to reduce animal handling to a minimum, one live IBR marker vaccine and one inactivated BVD vaccine with a proven fetal protection claim can be applied on the same day. the safety of the simultaneous (inactivated vaccine serves as solvent for the live vaccine) [55] and the concurrent (vaccines injected at two different sites) use of the two vaccines had been tested under field conditions with no local or general reactions [56]. ). In order to respond to the market requirements and to improve the animal health in extensive cow calf herds, the protocol using an IBR marker live vaccine and a tetravalent which contains BVD inactivate, PI3 inactivate and BRSV live not only cover the reproductive viruses, but also the respiratory producing a broad immunity response in the herds.

There are some studies that demonstrated the benefit of vaccination against BVD and IBR. Casademunt et al. (2016) emonstrated that the use of HIPRABOVIS® BALANCE with BVD 1a strain in seronegative heifers provided significant protection against fetal infection when the herd was subsequently exposed to a high level of natural BVD challenge during gestation. In a metaanalysis by Newcomer et al. (2015) demonstrated a quantitative benefit in BVD vaccination, with a $45 \%$ decrease in the number of abortions, an $85 \%$ decrease in fetal infections, and a 5\% increase in pregnancy risk when compared vaccinated animals with unvaccinated co-inhabitants.

Regarding IBR, Newcomer (2017) demonstrated a $60 \%$ decrease in the risk of abortions in vaccinated cattle supporting the benefit of bovine herpesvirus 1 vaccination in the prevention of abortions.

Pereira and collaborators [27] demonstrated that vaccination against IBR, BVD using a commercial vaccine improved reproductive efficiency parameters in herds without a history of vaccinating the cow herd against these reproductive pathogens, Moreover, cows should receive [57-60] both doses of the vaccine prior to AI to ensure maximum antibody response and optimal reproductive outcomes during conception, as well as early- and mid-gestation. In our study, it was demonstrated that an herd health management, in which the use of commercial vaccines for IBR and BVD, PI3 and BRSV there was a substantial reduction of the interval between births, influenced the actual fertility rate. The group of cows vaccinated presented a value of 471 days \pm 35 days whereas in the group of unvaccinated cows the value increased for $889 \pm 25$ days. Pereira et alin their experiment saw that cows vaccinated with BVD and IBR vaccine had greater pregnancy rate groups also non vaccinated cows and pregnancy loss differ between groups also [27]. Accordingly, the incidence of pregnancy losses was reduced, as well as statistically insignificant, in ranches that vaccinated cattle against IBR, BVD, compared with ranches that did not vaccinate. Beginning the vaccination program before estrus synchronization further increased its benefits on pregnancy rates on Days 30 and 120, whereas it reduced, to some extent, pregnancy 
losses. This outcome was attributed to the profile and timing of antibody responses upon vaccination using the vaccine.

\section{Conclusion}

Results of the present research clearly demonstrated that the vaccination of the Brava dos Açores bullfighting animals with a broad vaccination protocol against IBR, BVD, BRSV and PI3 substantially improved the reproductive events of these animals [61]. The results where the benefits were most pronounced were in the interval between calvings, where values decreased from 889 \pm 25 to $471 \pm 35$ days respectively to unvaccinated and vaccinated females. This great improvement led that the real fertility raised from $28.6 \%$ of the unvaccinated group to $71.1 \%$ for the vaccinated group [62].

\section{Acknowledgments}

This project was financed in $85 \%$ by FEDER and in $15 \%$ with regional funds through the Programa Operacional Açores 2020 (Operational Program Azores 2020), in scope of the project «BEMAP-ET - ACORES-01-0145-FEDER-000026.

\section{Conflict of Interests}

The authors declare the absence of any economic or conflict of interest related to this research.

\section{References}

1. Carpio I (2010) La crianza del toro bravo: un presente que mira al futuro y un futuro potenciador del pasado. Revista Profesión Veterinária 16: 94-96.

2. Pucariço FMN (2015) Estudo do Impacto Socioeconómico da Capeia Arraiana. Tese de Mestrado em Medicina Veterinária. Lisboa: Faculdade de Medicina Veterinária -Universidade de Lisboa.

3. Gomes M (2016) Caracterização do modo de produção da raça Brava de Lidecaso de estudo da ganadaria Murteira Grave. Dissertação para obtenção do Grau de Mestre em Engenharia Agronómica - AgroPecuária. Instituto Superior de Agronomia Universidade de Lisboa.

4. Seidel GE, Whittier JC (2015) Beef Species Symposium: Beef production without mature cows. J Anim Sci 93(9): 4244-4251.

5. Wikse S (2005) Management of infectious reproductive diseases in beef cattle herds. Applied Reproductive Strategies in Beef Cattle Texas A\&M University, USA.

6. Dziuk PJ, Bellows RA (1983) Management of Reproduction of Beef Cattle, Sheep and Pigs. Journal of Animal Science 57(2): 355-379.

7. Domaradzki P, Stanek P, Litwińczuk Z, Skałecki P, Florek M (2017) Slaughter value and meat quality of suckler calves: A review. Meat Sci 134: 135-149.

8. Berg DK, van Leeuwen J, Beaumont S, Berg M, Pfeffer PL (2010) Embryo loss in cattle between Days 7 and 16 of pregnancy. Theriogenology 73(2): 250-260.

9. Flores A (1971) A study of calving interval. Iowa State University Retrospective Theses and Dissertations 4452.

10. Diskin MG, Kenny DA (2016) Managing the reproductive performance of beef cows. Theriogenology 86(1): 379-387.

11. Ifende VI, Derks M, Hooijer GA, Hogeveen H (2014) Financial aspects of veterinary herd health management programmes. Vet Rec 175(9): 224.
12. Scheid Filho V, Schiavon R, Gastal G, Timm C, Lucia Jr T (2012) Association of the occurrence of some diseases with reproductive performance and milk production of dairy herds in southern Brazil. $\mathrm{R}$ Bras Zootec 41(2): 467-471.

13. Han JH, Weir AM, Weston JF, Heuer C, Gates MC (2018) Elimination of bovine viral diarrhea virus in New Zealand: a review of research progress and future directions. N Z Vet J 66(6): 273-280.

14. Raboisson D, Citerne P (2018) Marginal cost of the calving interval in beef cows is not uniform. Vet Rec 183(5): 160.

15. Wikse S (2005) Management of infectious reproductive diseases in beef cattle herds. Applied Reproductive Strategies in Beef Cattle Texas A\&M University, USA.

16. Walz PH, Edmondson MA, Riddell KP, Braden TD, Gard JA, et al. (2015) Effect of vaccination with a multivalent modified-live viral vaccine on reproductive performance in synchronized beef heifers. Theriogenology 83(5): 822-831.

17. Anderson M (2000) Procedimientos de diagnóstico del aborto en ganado vacuno. Prod Anim 156: 12-32.

18. Pessoa GA, Martini AP, Sá Filho MF, Batistella Rubin MI (2018) Resynchronization improves reproductive efficiency of suckled Bos taurus beef cows subjected to spring-summer or autumn-winter breeding season in South Brazil. Theriogenology. 122: 14-22.

19. Adu-Addai B, Koney EB, Addo P, Kaneene J, Mackenzie C, Agnew DW (2012) Importance of infectious bovine reproductive diseases: an example from Ghana. Vet Rec 171(2): 47.

20. Renault V, Damiaans B, Sarrazin S, Humblet MF, Lomba M, et al. (2018) Classification of adult cattle infectious diseases: A first step towards prioritization of biosecurity measures. Transbound Emerg Dis 65(6): 1991-2005.

21. Mehmet F, Veysel S, Ataseven SA, Cengiz Y (2016) Estimation of production and reproductive performance losses in dairy cattle due to bovine herpesvirus 1 (BoHV-1) infection. Veterinarski Arhiv 86(4): 499-513.

22. Fray MD, Paton DJ, Alenius S (2000) The effects of bovine viral diarrhoea virus on cattle reproduction in relation to disease control. Anim Reprod Sci 60-61: 615-627.

23. Grooms DL (2004) Reproductive consequences of infection with bovine viral diarrhea virus. Vet Clin North Am Food Anim Pract 20(1): 5-19.

24. Grooms DL, Bolin SR, Coe PH, Borges RJ, Coutu CE (2007) Fetal protection 308 against continual exposure to bovine viral diarrhea virus following administration of a 309-vaccine containing an inactivated bovine viral diarrhea virus fraction to cattle. Am J Vet 68(12): 1417-1422.

25. Schumaher TF, Cooke RF, Brandão AP, Schubach KM, de Sousa OA, Bohnert DW, et al. (2019) Effects of vaccination timing against respiratory pathogens on performance, antibody response, and health in feedlot cattle. J Anim Sci 2019 97(2): 620-630.

26. Cortese VS, Woolums A, Hurley DJ, Berghaus R, Bernard JK, Short TH (2017) Comparison of interferon and bovine herpesvirus-1-specific IgA levels in nasal secretions of dairy cattle administered an intranasal modified live viral vaccine prior to calving or on the day of calving. Vet Immunol Immunopathol 187: 35-41.

27. O'Connor, ML, Baldwin RS, Adams RS, Hutchinson LJ, et al. (1985) An Integrated Approach to Improving Reproductive Performance1, 2. Journal of Dairy Science 68(10): 2806-2816.

28. Pereira MH, Cooke RF, Alfieri AA, Vasconcelos JL (2013) Effects of vaccination against reproductive diseases on reproductive performance of lactating dairy cows submitted to AI. Anim Reprod Sci 137(3-4): 156-162.

29. Raboisson D, Citerne P (2018) Marginal cost of the calving interval in beef cows is not uniform. Vet Rec 183 (5):160. 
30. Olori VE, Meuwissen TH, Veerkamp, RF (2002) Calving interval and survival breeding values as measure of cow fertility in a pasture-based production system with seasonal calving. J Dairy Sci 85(3): 689-696.

31. Fiems LO, Ampe B (2014) Importance of dam BW change and calf birth weight in double-muscled Belgian Blue cattle and its relationship with parity and calving interval. Animal 9(1): 94-103.

32. Abdalla H, Elghafghuf A, Elsohaby I, Nasr MAF (2017) Maternal and non-maternal factors associated with late embryonic and early fetal losses in dairy cows. Theriogenology 15 (100): 16-23.

33. Aono FH, Cooke RF, Alfieri AA, Vasconcelos JL (2013) Effects of vaccination against reproductive diseases on reproductive performance of beef cows submitted to fixed-timed AI in Brazilian cow-calf operations. Theriogenology 79(2): 242-248.

34. Colitti B, Muratore E, Careddu ME, Bertolotti L, Iotti B, et al. (2018) Field application of an indirect gE ELISA on pooled milk samples for the control of IBR in free and marker vaccinated dairy herds. BMC Vet Res $14(1): 387$

35. Garoussi MT, Mehrzad J, Nejati A (2019) Investigation of persistent infection of bovine viral diarrhea virus (BVDV) in Holstein dairy cows. Trop Anim Health Prod 51(4): 853-858.

36. Potgeiter LND (1995) Immunology of Bovine virus diarrhea virus. Vet Clinics of North America: Food Animal Practice 11(3): 501-520.

37. Dubovi EJ (1994) Impact of bovine viral diarrhea virus on reproductive performance in cattle. Vet Clin North Am Food Anim Pract 10(3): 503 514.

38. Meyling A, Houe H, Jensen (1990) Epidemiology of bovine virus diarrhoea virus. AM. Rev Sci Tech 9(1): 75-93.

39. Houe H, Pedersen KM, Meyling A (1993) The effect of bovine virus diarrhea virus infection on conception rate. Preventive Veterinary Medicine 15(2-3): 117-123.

40. Heuer C, Healy A, Zerbini C (2007) Economic effects of exposure to bovine viral diarrhea virus on dairy herds in New Zealand. J Dairy Sci 90(12): 5428-5438.

41. Whitmore HL, Zemjamis R, Olson J (1981) Effect of bovine viral diarrhea virus on conception in cattle. J Am Vet Med Assoc 178: 10651067.

42. Grooms DL (2004) Reproductive consequences of infection with bovine viral diarrhea virus. Vet Clin North Am Food Anim Pract 20(1): 5-19.

43. Schelp C, Greiser-Wilke I, Wolf G, Beer M, Moennig V, et al. (1995) Identification of cell membrane proteins linked to susceptibility to bovine viral diarrhoea virus infection. Arch Virol 140(11): 1997-2009.

44. Thulke HH, Lange M, Tratalos JA, Clegg TA, McGrath G, et al. (2018) Eradicating BVD, reviewing Irish programme data and model predictions to support prospective decision making. Prev Vet Med 150: 151-161.

45. Lanyon SR, Hill FI, Reichel MP, Brownlie J (2013) Bovine viral diarrhea: pathogenesis and diagnosis. Vet J 199(2): 201-209.

46. Lanyon SR, Hill FI, Reichel MP, Brownlie J (2013) Bovine viral diarrhea: pathogenesis and diagnosis. Vet J 199(2): 201-209.

47. Gates MC, Evans CA, Weir AM, Heuer C, Weston JF (2019) Recommendations for the testing and control of bovine viral diarrhea in New Zealand pastoral cattle production systems. N Z Vet J 67(5): 219-227.

48. Raaperi K, Orro T, Viltrop A (2014) Epidemiology and control of bovine herpesvirus 1 infection in Europe. Vet J 201(3): 249-256.

49. Mahajan V, Banga HS, Deka D, Filia G, Gupta A (2013) Comparison of diagnostic tests for diagnosis of infectious bovine rhinotracheitis in natural cases of bovine abortion. J Comp Pathol 149(4): 391-401.

50. Lucy MC (2001) Reproductive loss in high-producing dairy cattle: where will it end? J Dairy Sci 84(6): 1277-1293.

51. Alvarez M, Bielsa JM, Santos L, Makoschey B (2007) Compatibility of a live infectious bovine rhinotraheitis (IBR) marker vaccine and an inactivated bovine viral diarrhea virus (BVDV) vaccine. Vaccine 25(36): 6613-6617.

52. Kaashoek MJ, Moerman A, Madić J, Rijsewijk FA, Quak J, et al. (1994) A conventionally attenuated glycoprotein E-negative strain of bovine herpesvirus type 1 is an efficacious and safe vaccine. Vaccine 12(5): 439-444.

53. Makoschey B, Beer M (2004) Assessment of the risk of transmission ofvaccine viruses by using insufficiently eleaned injections devices. Veterinary Record 155: 563-564.

54. De I Santman-Berends IMGA, Mars MH, Waldeck HWF, van Duijn L, Wever P, et al. (2018) Quantification of the probability of reintroduction of IBR in the Netherlands through cattle imports. Prev Vet Med 150: 168-175.

55. Mazan MR, Hoffman AM (2001) Effects of aerosolized albuterol on physiologic responses to exercise in standardbreds. Am J Vet Res 62(11): 1812-1817.

56. Richter V, Lebl K, Baumgartner W, Obritzhauser W, Käsbohrer A, et al. (2017) A systematic worldwide review of the direct monetary losses in cattle due to bovine viral diarrhoea virus infection. Vet J 220: 80-87.

57. Fulton RW (2013) Host response to bovine viral diarrhea virus and interactions with infectious agents in the feedlot and breeding herd. Biologicals 41(1): 31-38.

58. Geary TW (2005) Management strategies to reduce embryonic loss. The Range Beef Cow Symposium XIX, South Dakota.

59. Diskin MG, Kenny DA (2016) Managing the reproductive performance of beef cows. Theriogenology 86(1): 379-387.

60. Gates MC (2013) Evaluating the reproductive performance of British beef and dairy herds using national cattle movement records. Vet Rec 173(20): 499 .

61. Diskin M, Kenny D, Fisher G (2014) Achieving a 365-day calving interval in beef cows. The Business of Cattle' Teagasc, Grange, Dunsany, Ireland. Pp. 32-35.

62. Maizon DO, Oltenacu PA, Grohn YT, Strawderman RL, Emanuelson U (2004) Effects of diseases on reproductive performance in Swedish Red and White dairy cattle. Preventive Veterinary Medicine 66: 113-126.

63. Rani P, Dutt R, Singh G, Chandolia R (2018) Embryonic Mortality in Cattle- A Review. Int J Curr Microbiol App Sci 7(7): 1501-1516. 